\title{
Pityriasis Alba, a New Clinical Clue for Extrinsic Atopic Dermatitis
}

\author{
*11 Ghada F. Mohammed, ${ }^{1}$ Amal H. A. Gomaa, ${ }^{2}$ Alaael-din S. Abd-el-hamid, ${ }^{1}$ Moustafa \\ M. K. Eyada \\ ${ }^{1}$ Department of Dermatology and Venereology, ${ }^{2}$ Department of clinical pathology, Faculty of \\ Medicine, Suez Canal University, Ismailia, Egypt \\ Dr_Ghada77@hotmail.com,ahhussein10@hotmail.com,dralaasaad@yahoo.com \\ Meyada@yahoo.com
}

\begin{abstract}
:
Background: No clinical clues to differentiate between extrinsic atopic dermatitis (eAD) and intrinsic atopic dermatitis ( $i A D)$.

Aim: To compare presence of Pityriasis Alba (PA) in patients with extrinsic and intrinsic type of AD.

Subjects \& Methods: IL-4 and Ig-E were measured in 85 Patients' serum with enzyme linked immune sorbent assay (ELISA). Forty three patients with (eAD) (group I) (n=43) and forty two patients with (iAD) (group II) completed the study $(n=42)$.
\end{abstract}

Results: There was statistically significant correlation between PA and (eAD).

Conclusion: Pityriasis Alba could be used as a pathogenic clue in differentiating extrinsic AD from intrinsic $A D$.

Keywords: extrinsic atopic dermatitis; intrinsic atopic dermatitis; Immunoglobin-E; Interleukin-4; Pityriasis alba.

\section{INTRODUCTION}

The most common hypopigmentary disorder was Pityriasis Alba (24.7\%) [1]. PA is a skin disorder that presents with asymptomatic, ill-defined, slightly scaling patches with variable hypopigmentation [2]. Although its etiology is not well established, several factors are implicated including infection (Pityrosporum, Streptococcus, Aspergillus and Staphylococcus), nutritional deficiencies, atopy and dry skin, environmental factors (such as variations in temperature and air humidity, altitude and excessive exposure to sun) but none has been confirmed [3].

$\mathrm{AD}$ is categorized into two groups according to the laboratory findings and associated diseases. Nonallergic $\mathrm{AD}$, nonatopic eczema, atopiform dermatitis or nonatopic $\mathrm{AD}$ [4] are used interchangeably with intrinsic atopic dermatitis (iAD), which has normal serum IgE levels and it is found in a relevant pro-portion of all AD patients [5]. The extrinsic atopic dermatitis (eAD) is called IgE-associated dermatitis and is frequently related to allergic bronchial asthma or allergic rhinoconjunctivitis [6-8].

Interleukin-4 (IL-4) has a role in differentiation of naive helper T cells (Th0 cells) to Th2 cells. Afterwards, Th2 cells produce more IL-4 when activated by IL-4 which in turn leads to autocrine stimulation that prolongs Th2 responses. A prominent activity of IL-4 is the stimulation of class switching of the immunoglobulin genes of B cells [9]. Aggregation of antigens and binding of Ig-E to the FceRI on mast cells ends in releasing mediators from the cells like histamine, leukotrienes, and certain interleukins [10]. These chemicals cause many of the symptoms associated with allergy, such as local inflammation in eczema, airway constriction in asthma, increased vascular permeability, and increased mucus secretion in allergic rhinitis. These chemicals are presumed, to permit other immune cells to enter tissues, and lead to a potentially fatal drop in blood pressure as in anaphylaxis [9-10].

There aren't clinical diagnostic tools for distinguishing iAD from eAD (5). However, there is no report to compare the skin conditions between $\mathrm{AAD}$ and $\mathrm{ADD}$ patients. The purpose of this study was to compare the presence of PA in patients with extrinsic and intrinsic type of $\mathrm{AD}$ and if it could a clue for distinguishing them. 


\section{SUBJECTS AND METHODS}

\section{Subjects}

This descriptive comparative study was carried out in Dermatology outpatient clinic, Suez Canal University Hospital for a period of 6 months in accordance with the guidelines of the Helsinki Declaration, and was performed after obtaining the informed consent from all parents of the children.

By interviewing with 233 children; 148 were excluded because either receiving medical treatment, having other skin diseases, having other systemic diseases or those who refused to participate. So, only 85 patients with atopic dermatitis enrolled. Patients were assigned in two groups: 43 patients with (eAD) and 42 patients with (iAD) according to Tokura classification [11] by assessing them serologically (IgE), clinically, Immunologically (IL-4). IgE was considered to be normal if $<20 \mathrm{Iu} / \mathrm{ml}$, Borderline 20-100 Iu/ml, and high if $>100 \mathrm{Iu} / \mathrm{ml}$ (cut-off value for an elevated IgE level was set at 100 $\mathrm{IU} / \mathrm{ml}$ ) [12-13]. IL-4 cut off point $\geq 0.02 \mathrm{pg} / \mathrm{ml}[14]$

\section{Methods}

All of the studied patients were subjected to the following:

Full history-taking, general and systemic examination with special emphasis on presence or absence of PA. Serum levels of Ig-E and IL-4 were measured in all subjects by ELISA (a polystyrene microtiter plate) (ELISA kits from BD, USA) according to the manufacturer's protocol.

\section{STATISTICAL ANALYSIS}

Statistical analysis was performed using the program SPSS version 15 (SPSS Inc., Chicago, IL, USA). Quantitative data were expressed as mean \pm SD while qualitative data were expressed as numbers and percentages (\%). Student's t-test was used to test the significance of difference for quantitative variables that follow normal distribution and chi-square was used to test the significance of difference for qualitative variables. A probability value $(\mathrm{P}$ value $)<0.05$ was considered statistically significant.

\section{RESULTS}

In 85 patients, there were 50 females $(59.5 \%)$ and 34 males $(40.5 \%)$ with a mean age of $9.7 \pm 8.4$ years, ranging from 3 to 18 years. Serum level Ig-E and IL-4 were statistically significantly higher in eAD group versus iAD group. Mean \pm SD of serum level of Ig-E and IL-4 were $(230.26 \pm 277.14$ and $69.53 \pm 19.72)$ in eAD group versus $(72.76 \pm 125.13$ and $30.13 \pm 21.92)$ in $\mathrm{iAD}$ group respectively [Table (1)]. Family history of PA and AD was positive in $90.5 \%$ and $100 \%$ respectively in eAD group, which was significantly higher than iAD group [Table (2)]. There was a significant positive correlation between PA and eAD ( $\mathrm{r}=0.810$ and $\mathrm{P}$ value $<0.001)$ [Table (3)]

Table1. Demographic data of the Extrinsic $A D$ and Intrinsic $A D$

\begin{tabular}{|c|c|c|c|c|c|c|c|c|}
\hline \multirow{2}{*}{\multicolumn{3}{|c|}{ Variable }} & \multicolumn{2}{|c|}{ Extrinsic AD } & \multicolumn{2}{|c|}{ Intrinsic AD } & \multirow{3}{*}{\begin{tabular}{|c|} 
t-test \\
2.6 \\
\end{tabular}} & \multirow{3}{*}{$\begin{array}{c}\text { P- } \\
\text { value } \\
0.005^{*}\end{array}$} \\
\hline & & & No. & $\%$ & No. & $\%$ & & \\
\hline \multirow{4}{*}{$\begin{array}{l}\text { Ig-EE } \\
\text { Iu/ml }\end{array}$} & Normal & $<20$ & $\mathbf{0}$ & $\mathbf{0}$ & 39 & 92.8 & & \\
\hline & Borderline & $20-100$ & $\mathbf{0}$ & $\mathbf{0}$ & 3 & 7.1 & 2.7 & 0.008* \\
\hline & High & $>100$ & 43 & $100 \%$ & $\mathbf{0}$ & $\mathbf{0}$ & 2.3 & 0.009* \\
\hline & \multicolumn{2}{|c|}{ Mean \pm SD } & \multicolumn{2}{|c|}{$230.26 \pm 277.14$} & \multicolumn{2}{|c|}{$72.76 \pm 125.13$} & 2.71 & $0.008^{*}$ \\
\hline \multirow{3}{*}{$\begin{array}{c}\text { IL-4 } \\
\text { Pg/ml }\end{array}$} & \multicolumn{2}{|c|}{ High } & 41 & 95.3 & 4 & 9.5 & 1.1 & 0.008* \\
\hline & \multirow{2}{*}{\multicolumn{2}{|c|}{ Normal }} & 2 & 4.7 & 38 & 90.5 & 1.2 & 0.009* \\
\hline & & & & .72 & & 92 & 1.20 & $0.009^{*}$ \\
\hline
\end{tabular}

*Statistically significant difference

Table2. Comparison between level of IgE and IL-4 in Extrinsic AD and Intrinsic AD with and without family history of P. Alba

\begin{tabular}{|c|c|c|c|c|c|c|c|}
\hline & \multicolumn{2}{|c|}{ Extrinsic AD } & \multicolumn{2}{|c|}{ Intrinsic AD } & \multirow[t]{2}{*}{$\mathbf{U}$} & \multirow[t]{2}{*}{ P-value } \\
\hline & & No. & $\%$ & No. & $\%$ & & \\
\hline \multirow{2}{*}{$\begin{array}{l}\text { Family history } \\
\text { of P. Alba }\end{array}$} & $+v e$ & 39 & 90.7 & 2 & 4.8 & 41.00 & $0.049 *$ \\
\hline & - ve & 4 & 9.3 & 40 & 95.2 & 34.00 & $0.008^{*}$ \\
\hline \multirow{2}{*}{$\begin{array}{l}\text { Family history } \\
\text { of AD }\end{array}$} & $+v e$ & 43 & 100 & 5 & 11.9 & 55.00 & $0.04 *$ \\
\hline & - ve & 0 & 0 & 37 & 88.1 & 33.50 & $0.007 *$ \\
\hline
\end{tabular}

*Statistically significant difference

NS: no statistically significant difference 
Pityriasis Alba, a New Clinical Clue for Extrinsic Atopic Dermatitis

Table3. Relation between Pityriasis Alba and Extrinsic $A D$ and Intrinsic $A D$

\begin{tabular}{|c|c|c|c|c|c|l|l|}
\hline \multicolumn{2}{|c|}{} & \multicolumn{2}{|c|}{ Extrinsic AD } & \multicolumn{2}{c|}{ Intrinsic AD } & \multirow{2}{*}{ t-test } & \multirow{2}{*}{ P-value } \\
\cline { 2 - 8 } \multicolumn{2}{|c|}{} & No. & $\mathbf{\%}$ & No. & \% & & \\
\hline \multirow{2}{*}{ P. alba } & +ve & $\mathbf{4 2}$ & $\mathbf{9 7 . 7}$ & $\mathbf{2}$ & $\mathbf{4 . 8}$ & $0.810^{* *}$ & $<0.001$ \\
\cline { 2 - 8 } & -ve & $\mathbf{1}$ & $\mathbf{2 . 3}$ & $\mathbf{4 0}$ & $\mathbf{9 5 . 2}$ & $0.823^{* *}$ & $<0.001$ \\
\hline
\end{tabular}

** Correlation is significant at the 0.01 level (2-tailed).

\section{DisCUSSION}

PA is more prevalent in cold weather; this can be explained on the basis of increased skin dryness in winter. It is considered as one of the minor manifestations of atopy, although atopic symptoms are often not evident by the time PA appears. However, it is expected that those patients with PA will have AD later in their life [15].

Our study showed, significant elevation of serum level Ig-E and IL-4 in eAD versus iAD group. The results of this study agreed with Bardana 2004 and Ott et al (2009) [16, 17], serum IgE and IL-4 levels were found to be associated with allergen-specific $\operatorname{IgE}$ status. Serum $\operatorname{IgE}$ is considered to be a significant parameter for differentiation between eAD and iAD. Extrinsic AD is associated with high serum IgE and IL-4 levels and exhibits allergen-specific IgE to allergens and foods [16]. In contrast, intrinsic AD, with normal IgE levels (below 150-200 kU/L) [18, 19], low IL-4, and they do not have allergen-specific IgE to allergens and foods [16].

In 2008, Brenninkmeijer and colleagues found that $\mathrm{iAD}$ more in female, with high frequency of the Dennie-Morgan infra-orbital folds, late onset of the disease and milder disease severity [20]. However, Tokura $\mathrm{Y}$ suggested that the dermatological manifestations of eAD and iAD were indistinguishable [21]. Our study's results revealed a positive correlation of Pityriasis alba with eAD versus iAD. Thus, we could use Pityriasis alba as a significant clinical clue for differentiation between eAD and iAD. This also agreed with Al-mesari et al [22] as they found statistically significant higher IgE and IL-4 levels in patients with P. alba versus normal volunteers.

Skin barrier function is usually assessed by transepidermal water loss and skin surface hydration. The skin barrier function was preserved in iAD but impaired in eAD [23], probably because of filaggrin gene mutation [21,23]. Filaggrin mutations were statistically significantly correlated with high serum $\mathrm{IgE}$ and PA [24, 25]. By disturbing skin barrier, environmental allergens enter into the skin and increases density of Langerhans cells in the epidermis. After binding of environmental allergens to the IgE receptors on Langerhans cells, Th2 immune response and atopic inflammation triggered [26, 27].

In this study family history of AD and PA were significantly correlated with extrinsic AD. This can be explained by enhanced Th2 cell producing more IL-4 that may be related to genetic background and heredity. Also, Brenninkmeijer and colleagues found a less frequent association of intrinsic form with a family history of atopy and PA [20]

Finally, the PA was significantly correlated with extrinsic AD; we can consider it a pathognomonic clue in differentiating it from intrinsic type.

\section{Conclusion}

Pityriasis Alba could be used as a pathognomonic clue in differentiating extrinsic AD from intrinsic $\mathrm{AD}$.

\section{REFERENCES}

[1] Sori T, Nath AK, Thappa DM, and Jaisankar TJ. Hypopigmentary disorders in children in South India. Indian J Dermatol. 2011 Sep-Oct; 56(5): 546-549.

[2] Pinto FJ, Bolognia JL. "Disorders of hypopigmentation in children". Pediatr. Clin. North Am. 199138 (4): 991-1017.

[3] Zaynoun ST, Aftimos BG, Tenekjian KK, Bahuth N, Kurban AK.. Extensive pityriasis alba: a histological histochemical and ultrastructural study. Br J Dermatol; 1993. 108: 83-90.

[4] Akdis CA, Akdis M, Simon D, Dibbert B, Weber M, Gratzl S, Krey-den O, Disch R, Wuthrich B, Blaser K, Simon HU. T cells and T cell-derived cytokines as pathogenic factors in the nonallergic form of atopic dermatitis. J Invest Dermatol 1999; 113: 628-34.

[5] Schmid(-Grendelmeier) P, Simon D, Simon H, Akdis CA, Wuthrich B. Epidemiology, clinical features, and immunology of the "intrinsic" (non-IgE-mediated) type of atopic dermatitis (constitutional dermati-tis). Allergy 2001; 56: 841-9. 
[6] Kagi MK, Wuthrich B, Montano E, Barandun J, Blaser K, Walker C. Differential cytokine profiles in peripheral blood supernatants and skin biopsies from patients with different forms of atopic dermatitis, psoriasis and normal individuals. Int Arch Allergy Immunol 1994; 103: 33240.

[7] Walker C, Kagi MK, Ingold P, Braun P, Blaser K, Bruijnzeel-Koomen CAFM, Wuthrich B. Atopic dermatitis. correlation of peripheral blood $\mathrm{T}$ cell activation, eosinophilia and serum factors with clinical severity. Clin Exp Allergy 1993; 23: 145-53.

[8] Fabrizi G, Romano A, Vultaggio P, Bellegrandi S, Paganelli R, Venuti A. Heterogeneity of atopic dermatitis defined by the immune response to inhalant and food allergens. Eur J Dermatol 1999; 9: 380-4.

[9] Sokol CL, Barton GM, Farr AG and Medzhitov R. A mechanism for the initiation of allergen-induced T helper type 2 responses. Nat Immunol 2008. 9 (3): 310-318.

[10] Hofmann AM and Abraham SN. New roles for mast cells in modulating allergic reactions and immunity against pathogens. Curr Opin Immunol. Dec. 2009; 21(6):679-86.

[11] Tokura Y. Extrinsic and intrinsic types of atopic dermatitis. J Dermatol Sci. 2010 Apr; 58(1):17.

[12] Mancini I, Solé D, Naspitz CK. Níveis séricos de IgE total em crianças brasileiras normais no primeiro ano de vida. J Pediatr (Rio J) 1996;72(2):98-102.

[13] Spalding SM, Wald V, Bernd LAG. IgE sérica total em atópicos e não-atópicos na cidade de Porto Alegre. Ver Ass Med Barsil. 2000;46(2):93-7.

[14] Jones KP1, Morris RH, Rolf S, Whatley J, Davies BH. The assay of interleukin 4 in the serum of normal subjects and atopic patients using a novel immunoassay. Cytokine. 1997 Jul; 9(7):52934.

[15] Beliboni N and Yagyma M. An epidemiological study of pityriasis alba (sample of 300 cases). A Bras Dermatol 1975. 50: 135-140.

[16] Bardana EJ. Immunoglobulin E- (IgE) and non-IgE-mediated reactions in the pathogenesis of atopic eczema/dermatitis syndrome (AEDS). Allergy. 2004 Aug; 59 Suppl 78:25-9.

[17] Ott H, Stanzel S, Ocklenburg C, Merk HF, Baron JM, Lehmann S. Total serum IgE as a parameter to differentiate between intrinsic and extrinsic atopic dermatitis in children. Acta Derm Venereol 2009;89:257-61

[18] Schmid-Grendelmeier P, Simon D, Simon HU, Akdis CA, Wüthrich B. Epidemiology, clinical features, and immunology of the "intrinsic" (non-IgE-mediated) type of atopic dermatitis (constitutional dermatitis). Allergy 2001; 56:841-9.

[19] Fölster-Holst R, Pape M, Buss YL, Christophers E, Weichenthal M. Low prevalence of the intrinsic form of atopic dermatitis among adult patients. Allergy 2006; 61:629-32.

[20] Brenninkmeijer EE, Spuls PI, Legierse CM, Lindeboom R, Smitt JH, Bos JD. Clinical differences between atopic and atopiform dermatitis. J Am Acad Dermatol 2008; 58:407-14.

[21] Tokura Y. Extrinsic and intrinsic types of atopic dermatitis. J Dermatol Sci 2010; 58:1-7.

[22] Al-mesari TA, Gomaa AH, Abd-el-hamid AS, Mohammed GF, Eyada MM. Assessment of Serum Interleukin-4 and Immunoglobin E Levels in Pityriasis Alba Patients. J Turk Acad Dermatol2013; 7 (2): 1372a1.

[23] Mori T, Ishida K, Mukumoto S, Yamada Y, Imokawa G, Kabashima K, Kobayashi M, Bito T, Nakamura M, Ogasawara K, Tokura Y. Comparison of skin barrier function and sensory nerve electric current perception threshold between IgE-high extrinsic and IgE-normal intrinsic types of atopic dermatitis. Br J Dermatol 2010; 162:83-90.

[24] Akiyama M. FLG mutations in ichthyosis vulgaris and atopic eczema: spectrum of mutations and population genetics. Br J Dermatol 2010; 162:472-7.

[25] Landeck L, Visser M, Kezic S, John SM. Genotype-phenotype associations in filaggrin lossof-function mutation carriers. Contact Dermatitis. 2013 Mar; 68(3):149-55.

[26] Proksch E, Fölster-Holst R, Bräutigam M, Sepehrmanesh M, Pfeiffer S, Jensen JM. Role of the epidermal barrier in atopic dermatitis. J Dtsch Dermatol Ges 2009; 7:899-910.

[27] Bieber T. Atopic dermatitis. Ann Dermatol 2010;22:125-37. 